\title{
Impact of wheeled and tracked tractors on soil physical properties in a mixed conifer stand
}

\author{
Martina Cambi ${ }^{(1)}$, Giacomo Certini ${ }^{(2)}$, \\ Fabio Fabiano ${ }^{(1)}$, Cristiano Foderi ${ }^{(1)}$, \\ Andrea Laschi ${ }^{(1)}$, Rodolfo Picchio ${ }^{(3)}$
}

\begin{abstract}
Damage to forest soil caused by vehicle traffic mainly consists of soil compaction, displacement, and rut formation. Severity of the damage depends on vehicle mass, weight of the carried loads, ground morphology, and soil properties, such as moisture. This paper investigates the impacts of two types of vehicles (tracked or wheeled tractor), traffic intensities (one or five skidding cycles) and soil moisture ( $24 \%$ or $13 \%$ by weight) on compaction of a loam textured soil in a mixed conifer stand of central Italy. Changes in porosity, bulk density, shear and penetration resistances were analyzed. The latter three parameters were significantly higher in the trafficked soil portions than in the undisturbed ones in all treatments, while the opposite was true for porosity. The impact on soil bulk density and porosity was stronger for the wheeled tractor working on moist soil, while no significant effect of soil moisture was recorded for the tracked tractor. Shear and penetration resistances increased as a consequence of traffic, depending on both tractor type and soil moisture. The largest impact on shear resistance was recorded for the wheeled tractor on moist soil, while significant differences in penetration resistance were observed only between tracked and wheeled tractors in dry soil conditions. In order to preserve soil quality during logging activities, we recommend to operate under dry soil conditions and to limit vehicle movement on existing or new planned trails.
\end{abstract}

Keywords: Soil Compaction, Rutting, Skid Trails, Soil Degradation, Forest Management

te compaction of loose soils can result in improved soil quality (Gomez et al. 2002). Harvest-induced soil compaction depends on several factors: soil type (Berli et al. 2004, Sakai et al. 2008, Magagnotti et al. 2012), soil moisture (McNabb et al. 2001, Han et al. 2006, Ampoorter et al. 2012), content of soil organic matter (Arthur et al. 2013), number of machine passes (Williamson \& Neilsen 2000, Wallbrink et al. 2002, Han et al. 2006), terrain steepness and direction of travel (Jourgholami et al. 2014), characteristics of the equipment and yard organization (Picchio et al. 2012, Marchi et al. 2014), and machine speed and
(1) Dipartimento di Gestione dei Sistemi Agrari, Alimentari e Forestali (GESAAF), Università di Firenze. v. S. Bonaventura 13, I-50145 Firenze (Italy); (2) Dipartimento di Scienze delle Produzioni Agroalimentari e dell'Ambiente (DISPAA), Università di Firenze. p.le delle Cascine 18, I-50144 Firenze (Italy); (3) Dipartimento di Scienze e Tecnologie per l'Agricoltura, le Foreste, la Natura e l'Energia (DAFNE), Università della Tuscia, v. San Camillo De Lellis, I-01100 Viterbo (Italy)

@ Martina Cambi (martina.cambi@unifi.it)

Received: Jun 20, 2014 - Accepted: Jan 31, 2015

Citation: Cambi M, Certini G, Fabiano F, Foderi C, Laschi A, Picchio R (2015). Impact of wheeled and tracked tractors on soil physical properties in a mixed conifer stand. iForest 9: 89-94. - doi: 10.3832/ifor1382-008 [online 2015-05-22]

Communicated by: Elena Paoletti wheel slippage (Alakukku et al. 2003, Eliasson 2005). Soil compaction and reduction or removal of the top organic horizon often causes poor regeneration on skid trails (Rab 1996, Startsev \& McNabb 2000). With the exception of coarse-textured, excessively drained soils (Jakobsen \& Greacen 1985, Gomez et al. 2002), soil compaction reduces forest productivity (Brais 2001, Heninger et al. 2002, Ares et al. 2005) by impairing root elongation and decreasing water and air supply to plants and soil biota (Whalley et al. 1995). Soil compaction may also increase surface runoff and erosion (Rab 1996, Williamson \& Neilsen 2000, Christopher \& Visser 2007), hence the loss of the topmost fertile soil. Rutting is a frequent undesired result of forest logging and consists of grooves, caused by soil compression and displacement, which become preferential flow paths (Horn et al. 2007). Rut formation suggests that the load imposed onto the soil has exceeded its bearing capacity (Muro 1982). The weight of a loaded vehicle and the number of passes are major factors of rut formation (Jansson \& Johansson 1998, McNabb et al. 2001, Bygdén et al. 2004, Eliasson 2005). Ruts are usually more marked by wheeled vehicles than by tracked vehicles, due to higher pressure on soil, and for moist soil than for dry soil, due to the lubricant action of water on particles (Jansson \& Johansson 1998, Marchi et al. 2014). 
Few studies about the impact of logging on soil have been conducted in Mediterranean countries (e.g., Picchio et al. 2012, Jourgholami et al. 2014), which are among the most prone to erosion worldwide (Kosmas et al. 1997, Cerdà et al. 2010, Shakesby 2011). Moreover, the studies on soil compaction and rutting in relation to the machine type (tracked vs. wheeled) showed contrasting results (Cambi et al. 2015).

This study aims to evaluate the effects on soil compaction and rutting of wheeled and tracked tractors at two levels of soil moisture.

\section{Materials and methods}

\section{Description of the study area}

The study was carried out in the Rincine forest, a nature reserve $40 \mathrm{~km}$ northeast of Florence (central Italy). The mean annual precipitation in the period 2009-2013 was $1133 \mathrm{~mm}$, with the maximum in November and the minimum in July. In the same period, the mean annual temperature and the means of the coldest and warmest months (January and July) were $9.2{ }^{\circ} \mathrm{C}, 1.5{ }^{\circ} \mathrm{C}$ and $17.8{ }^{\circ} \mathrm{C}$, respectively. Soil developed on Lower Miocene-Oligocene sandstone and was classified as Dystric Cambisol based on the World Reference Base for Soil Resources (IUSS Working Group 2014).

The study site was a 30-years-old, evenaged plantation of Picea abies (L.) H. Karst, Pseudotsuga menziesii (Mirb.) Franco, Abies alba (Mill.), and Chamaecyparis spp. located at $900 \mathrm{~m}$ a.s.l. on a 5-10\% slope terrain. At the beginning of the experiment, the average duff thickness was measured on 60 points by a ruler with an accuracy of $\pm 0.5 \mathrm{~mm}$. Particle size distribution was determined using the hydrometer method, as described in Gee \& Bauder (1986), on five samples of the top $30 \mathrm{~cm}$ of mineral soil, randomly distributed throughout the study area. Soil organic matter content was determined by loss on ignition (Heiri et al. 2001) on fifteen samples.

Two tractors were used in our study, a tracked New Holland $88-85\left(3908 \mathrm{~cm}^{3}\right.$ displacement and $62.5 \mathrm{~kW}$ power) with an empty mass of $4600 \mathrm{~kg}$ and a wheeled New Holland T $4050\left(4500 \mathrm{~cm}^{3}\right.$ displacement and $71 \mathrm{~kW}$ power) with an empty mass of $4145 \mathrm{~kg}$, equipped with power drive forestry (11.2-24.0) tires on the front axle and agroforest 410 (420/85-30) Trelleborg on the rear axle. Both types of tires had reinforced sidewalls and a cut-resistant rubber compound. Inflation pressures were $150 \mathrm{kPa}$ and $100 \mathrm{kPa}$ in the rear and front tires, respectively. To measure the contact area between the tire and the ground, we pulled a rope tightly around the portion of the tire on the ground, assuming a circular contact patch (Neri et al. 2007). The average contact pressure was determined to be $46 \mathrm{kPa}$ and $54 \mathrm{kPa}$ in the front and rear axles, respectively; they were assumed to be uniformly distributed over every point of the four contact areas.

Measurements of soil compaction and rutting were performed immediately before and after tractor passes. Since the aim was to investigate the effects of tracked and wheeled machines on soil disturbance, tractor passes were conducted without loads in order to avoid the impacts of the skidded logs on soil.

\section{Experimental design and measurements}

A split-plot design was applied to verify the impact of tractors on soil. Three $50 \times$ $50 \mathrm{~m}$ areas were divided into four $25 \times 25$ $\mathrm{m}$ plots. Two skid trails were marked within each plot, resulting in a total of 24 trails per tractor $(3 \times 4 \times 2=24)$. In each plot, one

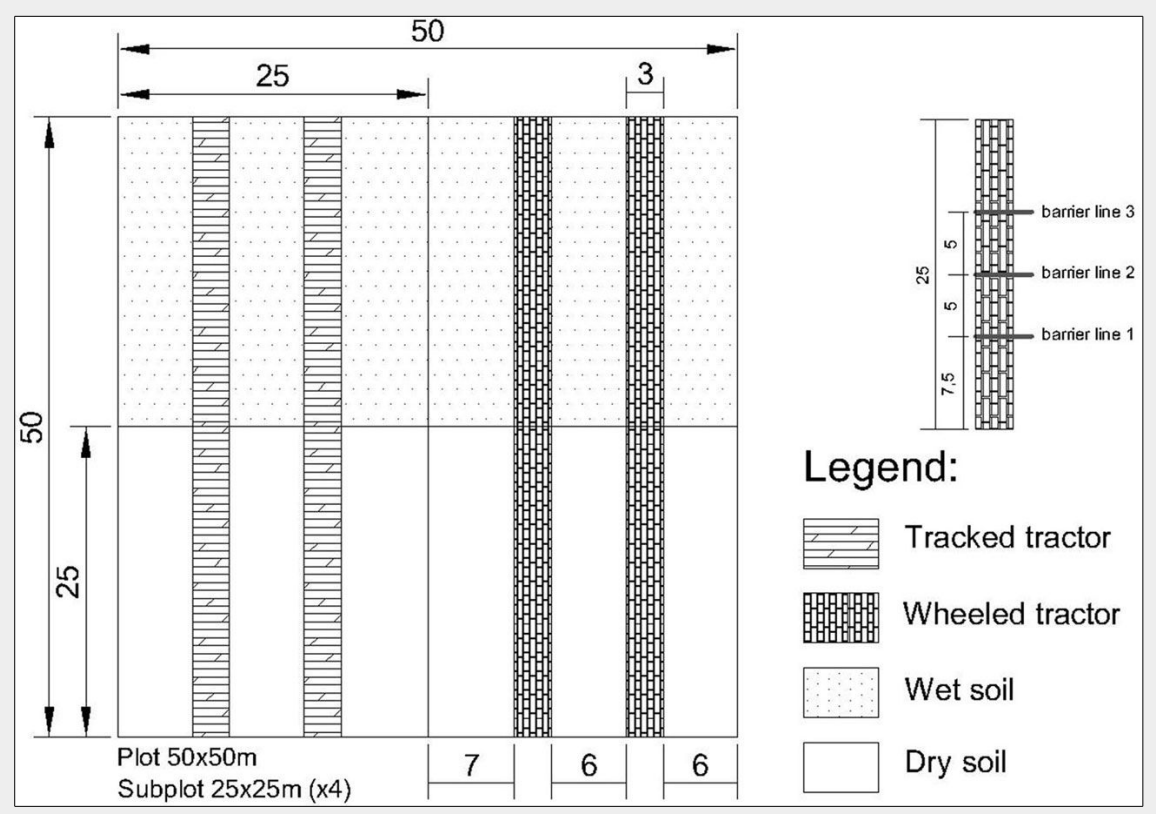

Fig. 1 - Sampling scheme of rut depth measurements. skid trail was trafficked with a tracked tractor and the other with a wheeled tractor. Half of all plots were trafficked when soil was relatively dry (11-13\% soil moisture) and the other half when the soil was moister (24-25\% soil moisture). Soil moisture was measured using a W.E.T. Sensor Kit (DeltaT Devices, Burwell, UK) at each sampling point. Treatments are hereafter called TD (tracked tractor on dry soil), TM (tracked tractor on moist soil), WD (wheeled tractor on dry soil), and WM (wheeled tractor on moist soil). Soil bulk density was measured after five tractor passes (one pass = one round trip), and rut depth was measured after one, three, and five passes. Five soil samples per skid trail and treatment - for a total of $30(5 \times 6)$ samples - were collected using a rigid metallic cylinder $(8.5 \mathrm{~cm}$ height and $5.0 \mathrm{~cm}$ inner diameter) after litter removal to determine bulk density. Thirty additional samples were collected at a distance of $2 \mathrm{~m}$ from the tracks before the tractor had passed and were used as control or undisturbed soil. Soil samples were weighed in the lab before ("moist weight") and after oven drying at $105^{\circ} \mathrm{C}$ to constant weight ("dry weight"). Soil porosity $(n)$ was determined by the following equation (Blake 1965 - eqn. 1 ):

$$
n=\frac{(D p-D b)}{D p} \cdot 100
$$

where $D p$ is the particle density measured by a pycnometer (Multipycnometer, Quantachrome, Boynton Beach, FL, USA) on the same soil samples used to determine the bulk density $(D b)$.

Penetration resistance and shear resistance were measured in triplicate close to each sampling point using a TONS/FT2 penetrometer and a GEONOR 72412 scissometer, respectively.

Three lines per skid trail were selected in order to evaluate the rutting (Fig. 1). The lines were orthogonal to the trail direction. On these lines, the distance between a horizontally leveled rod and the bottom of the rut was measured every $10 \mathrm{~cm}$ over the skid trail width section, both before trafficking and after one, three, and five passes of the tractor.

\section{Statistics}

Statistical analysis was carried out using the software package STATISTICA ${ }^{\circledR}$ ver. 7.1 (StatSoft, Tulsa, OK, USA). All data were checked for normality (Kolmogorov-Smirnov test) and homogeneity of variance (Levene's test). One-way and two-way ANOVA and MANOVA analysis and a posthoc Tukey's HSD test were applied to assess the statistical differences between groups. The non-parametric Kruskal-Wallis test was applied to bulk density data because of their heteroscedasticity. A nonlinear regression model was applied to determine the relationship between rut depth and the number of passes. 


\section{Results}

The litter+duff layer was $3.5 \pm 0.35 \mathrm{~cm}$ thick, while organic matter in the mineral soil averaged $106 \mathrm{~g} \mathrm{~kg}^{-1}$. Soil particle-size distribution fell in the loam region of the USDA triangle, the average values ( \pm standard deviations) of coarse sand, medium sand, fine sand, silt, and clay being $135 \pm 42$ $\mathrm{g} \mathrm{kg}^{-1}, 94 \pm 38 \mathrm{~g} \mathrm{~kg}^{-1}, 280 \pm 38 \mathrm{~g} \mathrm{~kg}^{-1}, 389 \pm$ $88 \mathrm{~g} \mathrm{~kg}^{-1}$, and $102 \pm 21 \mathrm{~g} \mathrm{~kg}^{-1}$, respectively. In all treatments, bulk density, and shear and penetration resistances were significantly higher in the trafficked soil portions than in the undisturbed ones, while the opposite was true for porosity (Tab. 1). A significant statistical difference in bulk density was recorded between the WD and WM treatments. The lowest increase with respect to the control was recorded with WD (26\%), while the highest increase was recorded with WM (33\%). No significant differences were recorded among wheeled and tracked treatments at the same soil moisture. Soil porosity showed a significant reduction relative to the control due to traffic in both soil moisture conditions. A significant difference in soil porosity was recorded between WD and WM. Shear and penetration resistances showed the highest increase when the wheeled tractor was used on moist soil (403\% and 50\%, respectively) and the lowest increase when the tracked tractor was used on dry soil $(211 \%$ and $28 \%$, respectively). Shear resistance was significantly higher for all the treatments in comparison with the control and showed significant differences between both tractor types and soil moisture conditions. Penetration resistance showed significant differences for all treatments in comparison to the control and between WD and TD.

Concerning rutting, one single pass created deeper ruts in moist soil than in dry soil with both wheeled and tracked tractors (Tab. 2). Three passes deepened the ruts further. The average depth increment compared to one pass was significantly different only between WM and TD. After five passes, the average rut depth increment compared to three passes did not show statistical differences among treatments.

The regression curves between passes and rut depth in moist and dry soils were statistically significant $(p<0.01)$ for the wheeled tractor (Tab. 3 and Fig. 2). The fitted models explained approximately $50 \%$ and $47 \%$ of the variation in the cumulative rut depth per number of skidding cycles for the moist and dry soils, respectively.

\section{Discussion}

The soil physical properties analyzed in this study (bulk density, porosity, and shear and penetration resistances) are generally assumed as the most representative for the assessment of the direct impact of vehicles on soil (Cambi et al. 2015). Indeed, they largely affect the soil biota because of their influence on gas and solution exchanges (Ballard 2000, Williamson \& Neilsen 2000). The logging-induced increa-

Tab. 1 - Soil moisture, bulk density, porosity, and shear and penetration resistances (mean \pm standard deviation) of the skid trails after five passes and of the controls. Different letters show statistically significant differences among treatments after Tukey's HSD tests ( $P<0.05, N=210)$. $(C D)$ : control in dry soil; $(C M)$; control in moist soil; (WD): wheeled tractor on dry soil; (TD); tracked tractor on dry soil; (WM); wheeled tractor on moist soil; (TM): tracked tractor on moist soil.

\begin{tabular}{lccccc}
\hline $\begin{array}{l}\text { Treat- } \\
\text { ment }\end{array}$ & $\begin{array}{c}\text { Soil moisture } \\
(\%)\end{array}$ & $\begin{array}{c}\text { Bulk density } \\
\left(\mathbf{g ~ c m} \mathbf{~ c m}^{-3}\right)\end{array}$ & $\begin{array}{c}\text { Porosity } \\
\mathbf{( \% )}\end{array}$ & $\begin{array}{c}\text { Shear } \\
\text { resistance } \\
\mathbf{( k P a )}\end{array}$ & $\begin{array}{c}\text { Penetration } \\
\text { resistance } \\
(\mathbf{M P a})\end{array}$ \\
\hline CD & $11.98 \pm 0.74^{\mathrm{a}}$ & $0.72 \pm 0.16^{\mathrm{c}}$ & $73 \pm 6^{\mathrm{c}}$ & $21.51 \pm 2.69^{\mathrm{c}}$ & $0.29 \pm 0.07^{\mathrm{c}}$ \\
WD & $11.58 \pm 0.66^{\mathrm{a}}$ & $0.91 \pm 0.02^{\mathrm{b}}$ & $65 \pm 6^{\mathrm{b}}$ & $88.67 \pm 5.60^{\mathrm{a}}$ & $0.42 \pm 0.06^{\mathrm{a}}$ \\
TD & $12.37 \pm 0.60^{\mathrm{a}}$ & $0.97 \pm 0.08^{\mathrm{ab}}$ & $63 \pm 3^{\mathrm{ab}}$ & $66.87 \pm 4.01^{\mathrm{b}}$ & $0.37 \pm 0.04^{\mathrm{b}}$ \\
CM & $24.47 \pm 0.80^{\mathrm{b}}$ & $0.77 \pm 0.11^{\mathrm{c}}$ & $71 \pm 4^{\mathrm{c}}$ & $19.12 \pm 4.95^{\mathrm{c}}$ & $0.26 \pm 0.05^{\mathrm{c}}$ \\
WM & $24.34 \pm 0.83^{\mathrm{b}}$ & $1.02 \pm 0.17^{\mathrm{a}}$ & $62 \pm 7^{\mathrm{a}}$ & $96.27 \pm 0.76^{\mathrm{e}}$ & $0.39 \pm 0.06^{\mathrm{ab}}$ \\
TM & $24.60 \pm 0.75^{\mathrm{b}}$ & $0.98 \pm 0.11^{\mathrm{ab}}$ & $63 \pm 4^{\mathrm{ab}}$ & $80.25 \pm 1.58^{\mathrm{d}}$ & $0.40 \pm 0.07^{\mathrm{b}}$ \\
\hline
\end{tabular}

Tab. 2 - Results of the one-way MANOVA for rut depths (mean \pm standard deviation, in $\mathrm{cm}$ ) in relation to the number of tractor passes. Wilks test's value: $0.86915, \mathrm{~F}_{[9]}=$ 22.144, $p=0.02082$. Different letters indicate statistically significant differences among treatments after Tukey's HSD test $(N=144)$. (WD): wheeled tractor on dry soil; (TD): tracked tractor on dry soil; (WM): wheeled tractor on moist soil; (TM): tracked tractor on moist soil; (1): average depth increment compared to 1 pass; (2): average depth increment compared to 3 passes.

\begin{tabular}{lcccc}
\hline Treatments & N & $\begin{array}{c}\text { Av. depth } \\
\text { (after 1 pass) }\end{array}$ & $\begin{array}{c}\text { Av. depth increment } \\
\text { (after 3 passes) }^{(1)}\end{array}$ & $\begin{array}{c}\text { Av. depth increment } \\
\text { (after 5 passes) }^{\left({ }^{2}\right)}\end{array}$ \\
\hline WD & 36 & $1.51 \pm 1.18^{\mathrm{b}}$ & $0.85 \pm 0.63^{\mathrm{ab}}$ & $0.44 \pm 0.47$ \\
TD & 36 & $1.64 \pm 2.88^{\mathrm{b}}$ & $0.53 \pm 0.30^{\mathrm{a}}$ & $0.60 \pm 0.72$ \\
WM & 36 & $2.84 \pm 1.77^{\mathrm{a}}$ & $1.10 \pm 0.82^{\mathrm{b}}$ & $0.52 \pm 0.43$ \\
TM & 36 & $3.41 \pm 6.32^{\mathrm{a}}$ & $0.95 \pm 0.97^{\mathrm{ab}}$ & $0.56 \pm 0.84$ \\
p-level & - & $<0.05$ & $<0.01$ & $>0.05$ \\
\hline
\end{tabular}

Tab. 3 - Regression summary for: (i) wheeled tractor on moist soil $\left(R^{2}=0.507, R_{\text {adjust }}^{2}=\right.$ $\left.0.500, \mathrm{~F}_{[2,141]}=72.598, \mathrm{p}<0.01\right)$; and (ii) wheeled tractor on dry soil $\left(R^{2}=0.478, R^{2}\right.$ adjust $=$ $\left.0.471, F_{[2,141]}=64.692, p<0.01\right)$. (SE): standard error.

\begin{tabular}{llcccccc}
\hline Group & Variable & Beta & SE & B & SE & t(141) & p-level \\
\hline (i) & $\mathrm{N}^{\circ}$ passes & -0.41682 & 0.209693 & -0.54195 & 0.272641 & -1.98776 & 0.048775 \\
& $\left(\mathrm{~N}^{\circ} \text { passes }\right)^{0.5}$ & 1.102428 & 0.209693 & 3.272679 & 0.622495 & 5.25735 & 0.000001 \\
\hline (ii) & $\left(\mathrm{N}^{\circ} \text { passages }\right)^{0.5}$ & 0.941042 & 0.215737 & 1.732946 & 0.397283 & 4.362 & 0.000025 \\
\hline
\end{tabular}

ses in soil bulk density found in this study were similar to or larger than most values obtained with comparable machinery and soil textures (e.g., McNabb et al. 2001, Picchio et al. 2012, Marchi et al. 2014).

Although the tracked tractor had lower

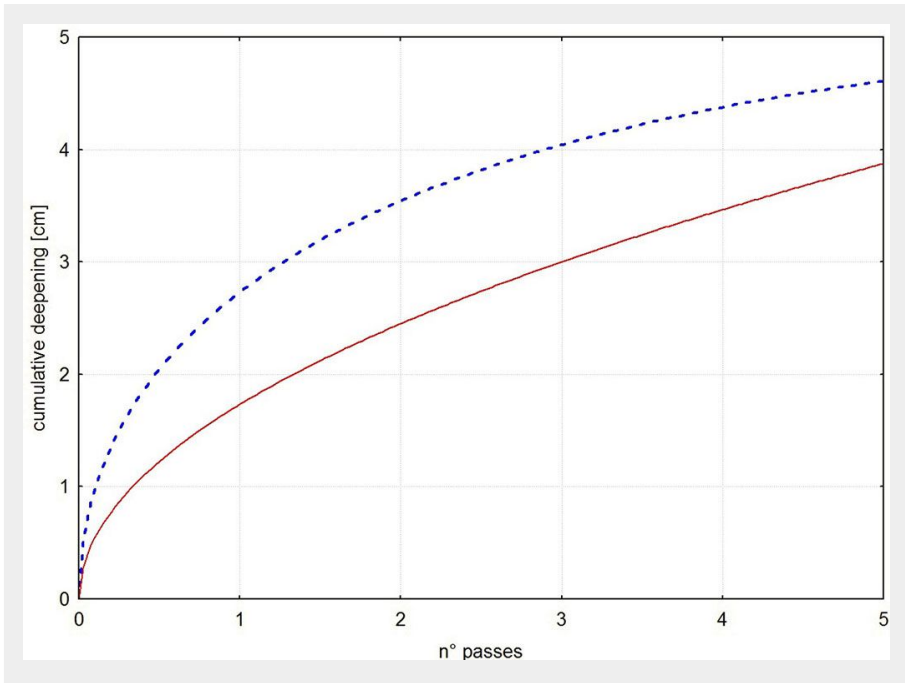

ground contact pressure ( $35 \mathrm{kPa}$ ) than the wheeled tractor ( $46 \mathrm{kPa}$ and $54 \mathrm{kPa}$ in the front and rear tires, respectively), no significant differences were found between the impact of the two vehicles on soil bulk den-
sity and porosity. Similar results were ob-

Fig. 2 - Regression curves between cumulative deepening of ruts and the number of passes for the wheeled tractor treatment (dotted curve: moist soil condition; continuous curve: dry soil condition). Error bars were not shown for clarity. Regression parameters are reported in Tab. 3. 
tained by Kamaruzaman (1991) on a clay loam soil at the Berkelah Forest Reserve in central Pahang (Malaysia), and by Sheridan (2003) on a silty clay loam forest soil at the Wombat State Forest, Victoria (Australia). Additional studies on the same topic reported contrasting results. Bashford et al. (1988) and Rusanov (1991) found that tracked tractors compacted the soil less than similar wheel tractors, while Spinelli et al. (2010) and Jansson \& Johansson (1998) found that the use of a tracked machine resulted in a higher increase in bulk density, in spite of its lower ground pressure and a more scattered stand traffic.

Our finding may be explained by the behavior of tracks and tires. In fact, the power drive systems of tracked vehicles produce more vibrations and have longer loading time than wheeled vehicles, thus causing higher dynamic stresses to soil (Wolf \& Hadas 1984, Wong \& Preston-Thomas 1984, Soane 1986). In crawler vehicles, the peak values of ground pressure that cause soil stresses may be three times higher than the average values (Koolen \& Kuipers 1983, Wolf \& Hadas 1984, Wong \& Preston-Thomas 1984, Wong 1986).

The impact on soil bulk density and porosity by both tractors could have been partly mitigated by the duff layer, which reduces the wheel/track pressure on the mineral soil. Nonetheless, the values of soil bulk density and porosity we measured could imply some constraints to plant growth and forest regeneration (Stirzaker et al. 1996, Zhao et al. 2010). In this regard, Heilman (1981) found that root penetration of 35- to 45-day-old Pseudotsuga menziesii seedlings declined linearly with the increase in soil bulk density, although it was substantially prevented only beyond $1.74 \mathrm{Mg}$ $\mathrm{m}^{-3}$.

The remarkable increase in soil shear resistance (200-400\%), which occurred with both vehicles and was higher with higher soil moisture, can hinder root elongation and soil workability. Even a moderate increase in penetration resistance (28-54\%) is an indicator of soil deterioration (Panayiotopoulos et al. 1994, Coelho et al. 2000), although much higher machinery-induced values were reported in the literature (Cambi et al. 2015).

Shear resistance was significantly lower in the TD treatment than in the other treatments, suggesting that the tracked tractor used on relatively dry soils was the preferable approach to remove logs from this study site. Such a conclusion is not fully supported by the results of bulk density and penetration resistance, as they refer to different soil top layers $(8.5 \mathrm{~cm}$ for bulk density, and only $2 \mathrm{~cm}$ for penetration resistance), while shear resistance was measured in the first $4 \mathrm{~cm}$.

Overall, the impact of the tracked tractor on soil was scarcely influenced by the soil moisture, which on the contrary, significantly increased the impact of the wheeled tractor. In particular, soil became more prone to rutting with increasing soil moisture. We conclude that wheeled tractors should be used only when soil moisture is low; crews should wait for one or more days after the last rainfall event if possible, depending on soil texture. In this study, measurements were carried out one week after the last rainfall; however, one single tractor pass was enough to cause rut formation on the skid trail. We also assessed that such impact of both tractors increased significantly with few additional passes, confirming the findings of other studies (Murosky \& Hassan 1991, Sheridan 2003, Eliasson 2005, Ampoorter et al. 2007, Silva et al. 2007).

\section{Conclusions}

Our study showed that basic physical properties of a loam forest soil - bulk density, porosity, and shear and penetration resistances - were significantly modified by few tractor passes. The extent of such modifications depended on the type of tractor and soil moisture. Tractor passes (one to five) clearly affected rut depth, though the average rut depth increment decreased with the number of passes. Deep ruts occurred in moist soil with just a single pass. The largest negative impact on soil occurred when using the wheeled tractor on moist soil. In this case, however, the post-harvest soil bulk density and penetration resistance did not reach values potentially harmful to stand productivity and regeneration. Using the tracked tractor on dry soil minimized the impact, especially in terms of shear and penetration resistances.

Based on the above considerations, it is highly recommended to wait for soil to be as much dry as possible before skidding. Moreover, the use of tracked tractors in wet conditions is preferable in terms of soil conservation. Further research performed across a wider range of soil types and logging systems is needed to obtain a more comprehensive insight on this topic.

\section{Acknowledgements}

We are indebted to the Union of Mountain Municipalities of Valdarno and Valdisieve, in particular to Dr. Antonio Ventre and Dr. lacopo Battaglini, managers of the Rincine forest, for performing the thinning and other related operations according to our recommendations.

\section{References}

Alakukku L, Weisskopf P, Chamen WC, Tijink FG, Van Der Linden J, Pires S, Sommer C, Spoor G (2003). Prevention strategies for field trafficinduced subsoil compaction: a review. Soil and Tillage Research 73: 145-160. - doi: 10.1016/So1 67-1987(03)00107-7

Ampoorter E, Goris R, Cornelis WM, Verheyen K (2007). Impact of mechanized logging on compaction status of sandy forest soils. Forest Ecology and Management 241: 162-174. - doi: 10.101 6/j.foreco.2007.01.019

Ampoorter E, Schrijver A, Nevel L, Hermy M.,
Verheyen K (2012). Impact of mechanized harvesting on compaction of sandy and clayey forest soils: results of a meta-analysis. Annals of Forest Science 69: 533-542. - doi: 10.1007/s1359 5-012-0199-y

Ares A, Terry T, Miller R, Anderson H, Flaming B (2005). Ground-based forest harvesting effects on soil physical properties and Douglas-fir growth. Soil Science Society of America Journal 69: 1822-1832. - doi: 10.2136/sssaj2004.0331 Arthur E, Schjønning P, Moldrup P, Tuller M, de Jonge $L$ (2013). Density and permeability of a loess soil: long-term organic matter effect and the response to compressive stress. Geoderma 193-194: 236-245. - doi: 10.1016/j.geoderma.201 2.09.001

Bagheri I, Kalhori SB, Akef M, Khormali F (2011). Effect of compaction on physical and micromorphological properties of forest soils. American Journal of Plant Science 3: 159-163. - doi: 10.4236/ajps.2012.31018

Ballard TM (2000). Impacts of forest management on northern forest soils. Forest Ecology and Management 133 (1-2): 37-42. - doi: 10.1016/ S0378-1127(99)00296-0

Bashford LL, Jones AJ, Mielke LN (1988). Comparison of bulk density beneath a belt track and tire. Applied Engineering in Agriculture 4: 122125. - doi: $10.13031 / 2013.26593$

Berli M, Kulli B, Attinger W, Keller M, Leuenberger J, Flühler $\mathrm{H}$, Springman SM, Schulin, R (2004). Compaction of agricultural and forest subsoils by tracked heavy construction machinery. Soil and Tillage Research 75: 37-52. - doi: 10.1016/S0167-1987(03)00160-0

Blake GR (1965). Particle density. In: "Methods of Soil Analysis, Part I" (Black CA ed). Agronomy Monographs no. 9, American Society of Agronomy, Madison, WI, USA, pp. 371-373.

Brais S (2001). Persistence of soil compaction and effects on seedling growth in northwestern Quebec. Science Society of America Journal 65: 1263-1271. - doi: 10.2136/sssaj2001.6541263x Bygdén G, Eliasson L, Wästerlund I (2004). Rut depth, soil compaction and rolling resistance when using bogie tracks. Journal of Terramechanics 40: 179-190. - doi: 10.1016/j.jterra.2003. 12.001

Cambi M, Certini G, Neri F, Marchi E (2015). The impact of heavy traffic on forest soils: a review. Forest Ecology and Management 338: 124-138. doi: 10.1016/j.foreco.2014.11.022

Cerdà A, Romero-Diaz A, Hooke J, Montanarella $L$ (2010). Soil erosion and degradation in Mediterranean-type ecosystems. Preface. Land Degradation and Development 21: 71-74. - doi: 10.1002/ldr.968

Christopher E, Visser R (2007). Methodology for evaluating post harvest erosion risk for the protection of water quality. New Zealand Journal of Forest Science 54: 20-25. [online] URL: http:// www.nzjf.org/free_issues/NZJF52_2_2007/09B D57F4-FF32-4095-A22E-50579B1F1CE4.pdf Coelho MB, Mateos L, Villalobos FJ (2000). Influence of a compacted loam subsoil layer on growth and yield of irrigated cotton in Southern Spain. Soil and Tillage Research 57: 129142. - doi: 10.1016/S0167-1987(00)00153-7 Eliasson L (2005). Effects of forwarder tyre pressure on rut formation and soil compaction. Silva Fennica 39: 549-557. - doi: 10.14214/sf.366 
Gee GW, Bauder JW (1986). Particle-size analysis. In: "Methods of Soil Analysis ( $2^{\text {nd }}$ edn)- Part I" (Klute A ed). Agronomy Monographs no. 9, American Society of Agronomy and Soil Science of Society of America, Madison, WI, USA, pp. 383-411. [online] URL: https://dl.scienceso cieties.org/publications/books/abstracts/sssabo okseries/methodsofsoilan1/383/preview

Gomez A, Powers RF, Singer MJ, Horwath WR (2002). Soil compaction effects on growth of young Ponderosa pine following litter removal in California's Sierra Nevada. Soil Science Society of America Journal 66: 1334-1343. - doi: 10.2136/sssaj2002.1334

Han HS, Page-Dumroese DS, Han SK, Tirocke J (2006). Effect of slash, machine passes, and soil moisture on penetration resistance in a cut-tolength harvesting. International Journal of Impact Engineering 17: 11-24.

Heilman P (1981). Root penetration of Douglasfir seedlings into compacted soil. Forest Science 27: 660-666. [online] URL: http://www. ingentaconnect.com/content/saf/fs/1981/00000 027/00000004/art00007

Heiri O, Lotter AF, Lamcke G (2001). Loss on ignition as a method for estimating organic and carbonate content in sediments: reproducibility and comparability of results. Journal of Paleontology 25: 101-110. - doi: 10.1023/A:1008119611481 Heninger R, Scott W, Dobkowski A, Miller R, Anderson H, Duke S (2002). Soil disturbance and 10-year growth response of coast Douglasfir on non-tilled and tilled skid trails in the Oregon Cascades. Canadian Journal of Forest Research 32: 233-246. - doi: 10.1139/x01-195

Horn R, Vossbrink J, Peth S, Becker S (2007). Impact of modern forest vehicles on soil physical properties. Forest Ecology and Management 248: 56-63. - doi: 10.1016/j.foreco.2007.02. 037

Huang J, Lacey J, Ryan PJ (1996). Impact of forest harvesting on the hydraulic properties of surface soil. Soil Science 161: 79-86. - doi: 10.109 7/00010694-199602000-00001

IUSS Working Group WRB (2014). World reference base for soil resources 2014. International soil classification system for naming soils and creating legends for soil maps. World Soil Resources Reports no. 106, FAO, Rome, Italy, pp. 181.

Kamaruzaman J (1991). Effect of tracked and rubber-tyred logging machines on soil physical properties of the Berkelah Forest Reserve, Malaysia. Pertanika 14: 265-276. [online] URL: http://psasir.upm.edu.my/2855/

Koolen AJ, Kuipers H (1983). Agricultural soil mechanics. Springer-Verlag, Berlin, Germany, pp. 241. [online] URL: http://www.cabdirect. org/abstracts/19841982473.html

Kosmas C, Danalatos N, Cammeraat LH, Chabart M, Diamantopoulos J, Farand R, Gutierrez L, Jacob A, Marques $H$, Martinez-Fernandez J, Mizara A, Moustakas N, Nicolau JM, Oliveros C, Pinna G, Puddu R, Puigdefabregas J, Roxo M, Simao A, Stamou G, Tomasi N, Usai D, Vacca A (1997). The effect of land use on runoff and soil erosion rates under Mediterranean conditions. Catena 29: 45-59. - doi: 10.1016/S0341-8162(96) 00062-8

Jakobsen BF, Greacen EL (1985). Compaction of sandy forest soils by forwarder operations. Soil and Tillage Research 5: 55-70. - doi: 10.1016/So1 67-1987(85)80016-7

Jamshidi R, Jaeger D, Raafatnia N, Tabari M (2008). Influence of two ground-based skidding systems on soil compaction under different slope and gradient conditions. International Journal of Engineering Science 19: 9-16. [online] URL: http://www.tandfonline.com/doi/ abs/10.1080/14942119.2008.10702554

Jansson KJ, Johansson J (1998). Soil changes after traffic with a tracked and wheeled forest machine: a case study on a silt loam in Sweden. Forestry 71: 57-66. - doi: 10.1093/forestry/71.1.57 Jourgholami M, Shoukuh S, Maryam E, Eric KZ (2014). Influence of slope on physical soil disturbance due to farm tractor forwarding in a Hyrcanian forest of northern Iran. iForest 7: 342-348. - doi: 10.3832/ifor1141-007

Magagnotti N, Spinelli R, Güldner O, Erler J (2012). Site impact after motor-manual and mechanised thinning in Mediterranean pine plantations. Ecological Engineering 113: 140-147. doi: 10.1016/j.biosystemseng.2012.07.001

Marchi E, Picchio R, Spinelli R, Verani S, Venanzi $R$, Certini G (2014). Environmental impact assessment of different logging methods in pine forests thinning. Ecological Engineering 70: 429436. - doi: 10.1016/j.ecoleng.2014.06.019

McNabb DH, Startsev AD, Nguyen H (2001). Soil wetness and traffic level effects on bulk density and air-filled porosity of compacted boreal forest soils. Soil Science Society of America Journal 65: 1238-1247. - doi: 10.2136/sssaj2001.65 $41238 x$

Muro T (1982). Tyres/wheels and tracks state-ofthe-art report. Journal of Terramechanics 19: 55-69. - doi: 10.1016/0022-4898(82)90027-1 Murosky DL, Hassan AE (1991). Impact of tracked and rubber-tired skidders traffic on a wetland site in Mississippi. Transactions of the ASAE 34: 322-327. - doi: 10.13031/2013.31665

Neri F, Spinelli R, Lyons J (2007). Ground pressure forwarder trials: assess benefits in reducing wheel rutting. In: Proceedings of the Meeting "Ground Pressure Forwarder Trials: Assess Benefits in Reducing Wheel Rutting". Austro2007/ FORMEC 2007 - Meeting the Needs of Tomorrows' Forests - New Developments in Forest Engineering. Vienna and Heiligenkreuz (Austria) 7-11 Oct 2007, pp. 1-10. [online] URL: http://www.formec.org/images/proceedings/20 07/session_5_pdf/5_2_paper_neri_spinelli_lyon s_austro_formec_2007.pdf

Panayiotopoulos KP, Papadopoulou CP, Hatjiioannidou A (1994). Compaction and penetration resistance indicates soil deterioration because it means reduced workability and more difficult soil exploration by roots. Soil Tillage and Research 31: 323-337. - doi: 10.1016/0167-1 987(94)90039-6

Picchio R, Neri F, Petrini E, Verani S, Marchi E, Certini G (2012). Machinery-induced soil compaction in thinning two pine stands in central Italy. Forest Ecology and Management 285: 3843. - doi: 10.1016/j.foreco.2012.08.008

Rab MA (1996). Soil physical and hydrological properties following logging and slash burning in the Eucalyptus regnans forest of southeastern Australia. Forest Ecology and Management 84: 159-175. - doi: 10.1016/0378-1127(96)03740-1 Rusanov VA (1991). Effects of wheel and track traffic on the soil and crop growth and yield. Soil and Tillage Research 19: 131-143. - doi: 10.101 6/0167-1987(91)90082-9

Sakai H, Nordfjell T, Suadicani K, Talbot B, Bollehuus $E$ (2008). Soil compaction on forest soils from different kinds of tyres and tracks and possibility of accurate estimate. Croatian Journal of Forest Engineering 29: 15-27. [online] URL: http://hrcak.srce.hr/index.php?show=clan ak\&id_clanak_jezik=40565\&lang=en

Schack-Kirchner $\mathrm{H}$, Fenner PT, Hildebrand EE (2007). Different responses in bulk density and saturated hydraulic conductivity to soil deformation by logging machinery on a Ferrasol under native forest. Soil Use and Management 23: 286-293. - doi: 10.1111/j.1475-2743.2007.0009 $6 . x$

Shakesby RA (2011). Post-wildfire soil erosion in the Mediterranean: review and future research directions. Earth-Science Reviews 105: 71-100. doi: 10.1016/j.earscirev.2011.01.001

Sheridan GJ (2003). A comparison of rubbertyred and steel-tracked skidders on forest soil physical properties. Australian Journal of Soil Research 41: 1063-1075. - doi: 10.1071/SR02090

Shestak CJ, Busse MD (2005). Compaction alters physical but not biological indices of soil health. Soil Science Society of America Journal 69: 236246. - doi: 10.2136/sssaj2005.0236

Silva SR, De Barros NF, Da Costa LM, De Sá Mendonça E, Leite FP (2007). Soil disturbances as affected by load and traffic intensity of a forwarder along interrows of a eucalypt stand. Revista Brasileira de Ciencia do Solo 31: 371-377. - doi: 10.1590/S0100-06832007000200019

Soane BD (1986). The role of organic matter in soil compactibility: a review of some practical aspects. Soil Tillage and Research 16: 179-201. doi: 10.1016/0167-1987(90)90029-D

Spinelli R, Magagnotti N, Nati C (2010). Benchmarking the impact of traditional small-scale logging systems used in Mediterranean forestry. Forest Ecology and Management 260 (11): 1997-2001. - doi: 10.1016/j.foreco.2010.08.048 Startsev AD, McNabb DH (2000). Effects of skidding on forest soil infiltration in west-central Alberta. Canadian Journal of Soil Science 80 : 617-624. - doi: 10.4141/S99-092

Stirzaker RJ, Passioura JB, Wilms Y (1996). Soil structure and plant growth: impact of bulk density and biopores. Plant and Soil 185: 151-162. doi: 10.1007/BF02257571

Teepe R, Brumme R, Beese F, Ludwig B (2004). Nitrous oxide emission and methane consumption following compaction of forest soils. Soil Science Society of America Journal 68: 605-611. - doi: 10.2136/sssaj2004.6050

Wallbrink PJ, Roddy BP, Olley JM (2002). A tracer budget quantifying soil redistribution on hill slopes after forest harvesting. Catena 47: 179201. - doi: 10.1016/S0341-8162(01)00185-0 Whalley W, Dumitru E, Dexter AR (1995). Biological effects of soil compaction. Soil Tillage and Research 35: 53-68. - doi: 10.1016/0167-1987(95) $00473-6$

Williamson JR, Neilsen WA (2000). The influence of soil and forest site on rate and extent of soil compaction and profile disturbance of skidtrails during ground based harvesting. Canadian Journal of Forest Research 30: 1196-1205. doi: 10.1139/xo0-041 
Wolf D, Hadas A (1984). Soil compaction effects on cotton emergence. Transactions of the American Society of Agricultural Engineers 27: 655-659. - doi: 10.13031/2013.32846

Wong YJ (1986). Computer aided analysis of the effects of design parameters on the performance of tracked vehicles. Journal of Terramechanics 23: 95-124. - doi: 10.1016/0022-4898(86)
90017-0

Wong JY, Preston-Thomas J (1984). A comparison between a conventional method and an improved method for predicting tracked vehicle performance. In: Proceedings of the " 8 th International Conference of the International Society of Terrain-Vehicles Systems". Cambridge (UK) 5-11 Aug 1984, pp. 361-380. [online]
URL: http://oai.dtic.mil/oai/oai?verb=getRecord \&metadataPrefix=html\&identifier=ADP004276 Zhao Y, Krzic M, Bulmer CE, Schmidt MG, Simard SW (2010). Relative bulk density as a measure of compaction and its influence on tree height. Canadian Journal of Forest Research 40: 17241735. - doi: 10.1139/X10-115 